\title{
MEMAHAMI CERITA RAKYAT MELALUI METODE INKUIRI
}

\author{
Irma $^{1}$, M. Amin Menne ${ }^{2}$, dan Jumiati Lanta ${ }^{3}$ \\ 1, 2,3 Universitas Muhammadiyah Sidenreng Rappang \\ Jalan Angkatan 45 No. 1A Lautang Salo Rappang \\ irma18@gmail.com
}

\begin{abstract}
Abstrak: Memahami Cerita Rakyat melalui Metode Inkuiri. Penelitian ini dilakukan di SMP Negeri 3 Panca Rijang dengan tujuan untuk mendeskripsikan kemampuan membaca pemahaman cerita rakyat dan mendeskripsikan pengaruh penggunaan metode inkuiri dalam pembelajaran membaca pemahaman siswa. Populasi penelitian ini adalah seluruh siswa kelas VII SMP Negeri 3 Panca Rijang yang berjumlah 68 orang, sedangkan sampelnya berjumlah 68 orang karena objeknya kurang dari 100 sehingga penelitian merupakan penelitian populasi. Metode pengumpulan data yang digunakan adalah dokumentasi dan tes. Data yang diperoleh dianalisis dengan teknik statistik deskriptif dalam bentuk mean. Berdasarkan hasil penelitian dapat disimpulkan bahwa ada pengaruh penggunaan metode inkuiri terhadap kemampuan siswa dalam membaca pemahaman cerita rakyat. Hal ini dilihat pada nilai antara kelompok eksperimen dengan kelompok kontrok yakni $\mathrm{M}_{\mathrm{x}}=81,94>\mathrm{M}_{\mathrm{y}}=76,97$. Perbedaan ini menunjukkan adanya pengaruh penggunaan metode inkuiri terhadap kemampuan membaca pemahaman cerita rakyat Siswa Kelas VII SMP Negeri 3 Panca Rijang.
\end{abstract}

Kata kunci: cerita rakyat, membaca pemahaman, metode inkuiri.

\begin{abstract}
Understanding Folklore through the Inquiry Method. This research was conducted at SMP Negeri 3 Panca Rijang with the aim of describing the ability to read comprehension of folklore and describe the effect of using the inquiry method in learning to read students' reading comprehension. The population of this study were all seventh grade students of SMP Negeri 3 Panca Rijang, totaling 68 people, while the sample was 68 people because the object was less than 100 so the study was a population study. Data collection methods used are documentation and tests. The data obtained were analyzed by descriptive statistical techniques in the form of the mean. Based on the results of the study, it can be concluded that there is an effect of using the inquiry method on students' ability to read and understand folklore. This can be seen in the value between the experimental group and the control group, namely $\mathrm{Mx}=81.94>\mathrm{My}=76.97$. This difference shows the effect of the use of the inquiry method on the ability to read and understand folklore for Grade VII students of SMP Negeri 3 Panca Rijang.
\end{abstract}

Keyword: folklore, reading comprehension, method of inquiry.

Membaca berperan sangat strategis dalam upaya pengembangan diri. Dengan membaca pemahaman ini, orang dapat menggali pengetahuan yang tersimpan dalam buku dan media tertulis lainnya. Membaca pemahaman ini diibaratkan sebagai kunci untuk membuka gudang pengetahuan Kita harus sadar akan pentingnya membaca, khususnya membaca pemahaman.
Pemahaman bacaan akan terus menjadi penting sebagai alat untuk mengeksplorasi berbagai bidang ilmu pengetahuan. Hal ini terutama dirasakan oleh mahasiswa. Membaca pemahaman akan membantu seseorang mengembangkan keterampilan akademik, kemampuan, dan kecerdasan. Dalam kehidupan masyarakat modern yang kompleks, kemampuan seseorang untuk 
memahami apa yang telah dibacanya sangat diperlukan dalam bidang pendidikan, ekonomi, dan sosial. Selain itu, pemahaman bacaan akan memberi pembaca keunggulan. Dalam hal ini, pembaca akan menerima informasi yang semakin beragam.

Cerita rakyat adalah cerita yang berkembang di suatu daerah tertentu dan dianggap sebagai kerja bersama dari penduduk daerah tersebut. Mendengarkan dan membaca cerita rakyat akan sangat bermanfaat. Salah satunya, kita akan mendapatkan pengalaman berharga dari cerita, melalui peristiwa yang dialami oleh para karakter. Ada pesan moral dalam cerita rakyat yang bermanfaat bagi pembaca. Pesan dalam cerita terkadang diungkapkan secara langsung, tetapi terkadang diungkapkan secara tidak langsung melalui perilaku para karakter. Cerita rakyat sering disebut juga dengan sastra lisan. Biasanya, cerita rakyat bersifat anonim atau pengarangnya tidak diketahui. Secara umum, cerita rakyat ini menceritakan tentang terjadinya atau asal usul suatu tempat. Tokoh yang muncul dalam cerita rakyat biasanya berwujud binatang, manusia, dan dewa.

Berdasarkan wawancara yang dilakukan penulis dengan guru Bahasa Indonesia di SMP Negeri 3 Panca Rijang, beliau menyatakan bahwa sebagian siswa kelas VII masih mengalami kesulitan dalam belajar membaca fiksi karena beberapa faktor, antara lain kurangnya motivasi siswa untuk membaca, masih ada kesalahan membaca dari segi ejaan, kurangnya waktu untuk latihan yang maksimal bagi siswa. Untuk menuntaskan masalah tersebut dibutuhkan metode pembelajaran yang tepat (Lanta, 2015; Ecca \& Lanta, 2018; Ririantika et al., 2020). Salah satu metode yang dapat digunakan adalah metode inkuiri. Melalui metode inkuiri, siswa dapat menemukan sendiri jawaban dari setiap masalah yang ditanyakan (Sanjaya, 2006).

\section{METODE}

Penelitian ini dilaksanakan untuk mengetahui ada tidaknya pengaruh metode inkuiri dalam pembelajaran membaca pemahaman cerita rakyat siswa. Populasi penelitian sebanyak 68 orang. Mengingat populasi kecil, maka digunakan sampel total (Arikunto, 2019). Data dikumpulkan melalui teknik dokumentasi dan tes. Selanjutnya diolah dan dianalisis dengan statistic deskriptif dalam bentuk mean (nilai rata-rata). Berikut ini langkah-langkah yang ditempuh dalam pengumpulan data.

a. Siswa dibagi menjadi dua kelompok, yaitu kelompok eksprimen dan kelompok kontrol, yang dilakukan secara acak tanpa memilih-milih.

b. Siswa diacak dengan membuat nomor urut mulai dari siswa yang bernomor stambuk terkecil sampai yang bernomor stambuk terbesar. Siswa yang bernomor urut ganjil dikelompokkan dalam kelompok eskprimen, sedangkan siswa yang bernomor urut genap dimasukkan ke dalam kelompok kontrol.

c. Masing-masing kelompok diberi sajian materi yang sama dalam pelajaran bahasa Indonesia sebanyak satu kali pertemuan.

d. Peneliti melaksanakan tugas mengajar secara bergantian kepada kedua kelompok siswa. Pada kelompok eksprimen, peneliti menggunakan metode inkuiri dalam pengajaran membaca pemahaman cerita rakyat, sedangkan pada kelompok kontrol tanpa menggunakan metode inkuiri.

e. Masing-masing kelompok diberi tes atau evaluasi yang sama pada akhir setiap pertemuan.

\section{HASIL DAN PEMBAHASAN}

\section{Hasil Penelitian}

Data yang disajikan berikut ini adalah hasil tes yang menggambarkan pengaruh penggunaan metode inkuiri terhadap kemampuan membaca pemahaman cerita rakyat siswa.

Tabel 1 Nilai, Kategori, dan Frekuensi Kelompok Eksperimen

\begin{tabular}{cccc}
\hline No. & Nilai & Kategori & Frekuensi \\
\hline 1 & $91-100$ & Sangat baik & 1 \\
\hline 2 & $81-90$ & Baik & 19 \\
\hline 3 & $71-80$ & Cukup & 13 \\
\hline 4 & $61-70$ & Kurang & 1 \\
\hline 5 & $\leq 60$ & $\begin{array}{c}\text { Sangat } \\
\text { Kurang }\end{array}$ & 0 \\
\hline \multicolumn{5}{c}{ Jumlah } & 34 \\
\hline
\end{tabular}

Sumber: Hasil tes 
Berdasarkan tabel tersebut diketahui bahwa siswa lebih dominan memperoleh nilai pada rentang 81-90 dengan kategori baik.

Tabel 2 Nilai, Kategori, dan Frekuensi Kelompok Kontrol

\begin{tabular}{cccc}
\hline No. & Nilai & Kategori & Frekuensi \\
\hline 1 & $91-100$ & Sangat baik & 0 \\
\hline 2 & $81-90$ & Baik & 6 \\
\hline 3 & $71-80$ & Cukup & 18 \\
\hline 4 & $61-70$ & Kurang & 9 \\
\hline 5 & $\leq 60$ & $\begin{array}{c}\text { Sangat } \\
\text { Kurang }\end{array}$ & 0 \\
\hline \multicolumn{5}{c}{ Jumlah } & 34
\end{tabular}

Sumber: Hasil tes

Berdasarkan tabel tersebut diketahui bahwa siswa lebih dominan memperoleh nilai pada rentang 71-80 dengan kategori cukup.

Tabel 3 Tabel Kerja Perhitungan Mean

\begin{tabular}{cccccc}
\hline & \multicolumn{2}{c}{$\begin{array}{c}\text { Kelompok } \\
\text { No. }\end{array}$} & \multicolumn{3}{c}{$\begin{array}{c}\text { Kelompok } \\
\text { Eksperimen }\end{array}$} \\
\cline { 2 - 6 } & $\mathrm{fx}$ & $\mathrm{f}$ & $\mathrm{x} \mathrm{\&} \mathrm{y}$ & $\mathrm{f}$ & fy \\
\hline 1 & 95 & 1 & 95 & & \\
\hline 2 & 450 & 5 & 90 & 1 & 90 \\
\hline 3 & 510 & 6 & 85 & 6 & 510 \\
\hline 4 & 656 & 8 & 82 & 8 & 640 \\
\hline 5 & 480 & 6 & 80 & 10 & 750 \\
\hline 6 & 525 & 7 & 75 & 8 & 560 \\
\hline 7 & 70 & 1 & 70 & 1 & 65 \\
\hline 8 & 0 & 0 & 65 & 0 & 0 \\
\hline$\sum$ & 2.786 & 34 & & 34 & 2.615 \\
\hline
\end{tabular}

Sumber: diolah dari tabel 1 dan 2

$$
\begin{aligned}
M_{x} & =\frac{\sum f x}{N} & M_{y} & =\frac{\Sigma f y}{N} \\
& =\frac{2.786}{34} & & =\frac{2.615}{34} \\
& =81,94 & & =76,91
\end{aligned}
$$

Berdasarkan hasil analisis data diperoleh nilai rata-rata kelompok eksperimen 81,94 dan kelompok kelompok kontrol 76,91. Hasil analisis data tersebut menunjukkan nilai rata-rata kelompok eksperimen lebih besar daripada nilai kelompok kontrol.

\section{Pembahasan}

Berdasarkan keseluruhan data penelitian penggunaan metode inkuiri terhadap kamampuan membaca pemahaman cerita rakyat yang dilakukan di ruang kelas VII dengan menggunakan metode inkuiri menunjukkan bahwa kemampuan membaca pemahaman cerita rakyat siswa kelas VII SMP Negeri 3 Panca Rijang Kecamatan Kulo Kabupaten Sidenreng Rappang tahun ajaran 2017-2018 yang berjumlah 68 siswa termasuk dalam kategori sangat baik (berpengaruh) dan mencapai ketuntasan belajar.

Hasil analisis data menunjukkan perbedaan nilai rata-rata kelompok eksperimen dan nilai rata-rata kelompok kontrol, yakni $\mathrm{Mx}=81,94$, lebih besar dari My $=76,91$. Hasil analisis data tersebut menunjukkan nilai rata-rata kelompok eksperimen lebih besar daripada nilai kelompok kontrol. Hal itu berarti ada Pengaruh Penggunaan Metode Inkuiri terhadap kemampuan membaca pemahaman cerita rakyat siswa kelas VII SMP Negeri 3 Panca Rijang Kecamatan Kulo Kabupaten Sidenreng Rappang tahun ajaran 2017-2018. Dengan demikian, hipotesis alternatif yang diajukan dalam penelitian ini diterima dan hipotesis nol ditolak.

Berdasarkan hasil wawancara peneliti dengan guru mata pelajaran Bahasa Indonesia dapat diketahui bahwa siswa mengalami kesulitan dalam memahami bacaa. Selain itu, guru juga belum menggunakan metode yang bervariasi dalam pembelajaran membaca pemahaman cerita rakyat. Saat pembelajaran membaca, siswa biasanya diberi waktu beberapa menit untuk membaca bacaan kemudian langsung mengerjakan soal yang diberikan guru. Akibatnya, kemampuan siswa dalam membaca pemahaman cerita rakyat kurang memuaskan.

Melihat kondisi tersebut, kegiatan membaca pemahaman cerita rakyat di kelas perlu mendapat perbaikan. Salah satu langkah yang diambli peneliti adalah mengembangkan variasi pembelajaran dengan menggunakan metode inkuiri agar kemampuan membaca pemahaman cerita rakyat siswa kelas VII SMP Negeri 3 Panca Rijang dapat meningkat.

Melalui metode inkuiri siswa dapat mengerti serta menemukan konsep dasar dan ide-ide yang tertuang dalam bahan bacaan 
(Sanjaya, 2006; Mulyasa, 2006; Ramdani, 2016; Manshur, 2016). Melalui metode inkuiri siswa juga akan terdorong untuk berpikir dan bekerja secara jujur dan terbuka dalam memahami bahan bacaan yang tidak mampu dipahami oleh siswa melalui waktu yang singkat. Dalam metode inkuiri siswa diberikan waktu yang cukup sehingga dapat menemukan data yang mendukung jawaban mereka.

Melalui metode inkuiri ini, kegiatan pembelajaran tidak lagi berpusat pada guru saja. Siswalah yang lebih aktif terlibat dalam kegiatan pembelajaran, sedangkan guru hanya sebagai fasilitator pembelajaran. Penerapan metode inkuiri ini direspon positif oleh siswa, sehingga suasana belajar menjadi menyenangkan dan mengakibatkan hasil belajar siswa dalam membaca pemahaman cerita rakyat lebih meningkat. Berdasarkan hasil tersebut dapat disimpulkan bahwa ada pengaruh penggunaan metode inkuiri terhadap kemampuan membaca pemahaman cerita rakyat siswa kelas VII SMP Negeri 3 Panca

\section{DAFTAR PUSTAKA}

Arikunto, S. (2019). Prosedur Penelitian. Rineka Cipta.

Ecca, S., \& Lanta, J. (2018). Penggunaan Teknik Teratai dalam Menulis Puisi. Seminar Nasional Bahasa Indonesia 1, 1(November 2018), 486-492.

Lanta, J. (2015). Pengajaran Cerpen melalui Strategi Multiple Intelliences di Sekolah Menengah. Seminar Internasional Bahasa, Sastra Dan Pembelajarannya, 147.

Manshur, A. (2016). Teknik Inkuiri Upaya Peningkatan Kemampuan Membaca Pemahaman Siswa SMP Plus Darussalam Blokagung Banyuwangi. Jurnal Darussalam: Jurnal Pendidikan, Komunikasi, Dan Pemikiran Hukum Islam., 8(1), 84-94.
Rijang Kecamatan Kulo Kabupaten Sidenreng Rappang.

\section{PENUTUP}

Berdasarkan hasil analisis data diperoleh nilai rata-rata kelompok eksperimen 81,94 dan kelompok kontrol 76,91. Hasil analisis data tersebut menunjukkan nilai ratarata kelompok eksperimen lebih besar daripada nilai kelompok kontrol. Hal itu berarti ada pengaruh penggunaan metode inkuiri terhadap kemampuan membaca pemahaman cerita rakyat siswa kelas VII SMP Negeri 3 Panca Rijang Kecamatan Kulo Kabupaten Sidenreng Rappang. Dengan demikian, disarankan agar metode inkuiri dijadikan alah satu alternatif untuk melatih kemandirian siswa dalam proses pembelajaran.

Mulyasa. (2006). Menjadi Guru Profesional Menciptakan Pembelajaran Kreatif dan Menyenangkan. PT Remaja Rosdakarya. Ramdani, D. (2016). Peningkatan Kemampuan Membaca Pemahaman Menggunakan Metode Inkuiri pada Siswa XI IPS SMA Wisuda Pontianak. Jurnal Pendidikan Dan Pembelajaran Khatulistiwa, 5(3).

Ririantika, R., M, U., Aswadi, A., \& Sakkir, G. (2020). Penerapan Model Pembelajaran Tipe "Make A Match" terhadap Hasil Belajar Bahasa Indonesia. Cakrawala Indonesia, 5(1), 1-6.

Sanjaya, W. (2006). Strategi Pembelajaran. Kencana Prenada Media Group. 